\title{
PENGARUH PERSEPSI ANAK TENTANG TAMAN BACAAN DAN MINAT TERHADAP KEBIASAAN MEMBACA PADA TAMAN BACAAN MASYARAKT MANCA PEKAYON BEKASI SELATAN
}

\author{
Sigit Widiyarto \\ Dosen Program Studi Pendidikan Sejarah Universitas Indraprasta PGRI \\ E-mail : sigit.widiyanto372@gmail.com
}

\begin{abstract}
Abstrak : Kebiasaan merupakan hal yang dilakukan berulang-ulang, tanpa adanya paksaaan. Hal ini dapat dilakukan secara periodik. Kebiasaan membaca merupakan proses menuju kehidupan manusia yang mulia. Kegiatan ini berhubungan dengan minat baca dan keberadaan Taman Bacaan yang tersebar di pelbagai daerah. Penelitian ini bertujuan untuk mengetahui persepsi tentang taman bacaan terhadap kebiasaan membaca dan mengetahui pengaruh minat baca terhadap kebiasaan membaca serta mengetahui persepsi tentang taman bacaan dan minat secara bersama-sama terhadap kebiasaan membaca. Metode yang digunakan dalam penelitian ini adalah metode survei. Hasil penelitian menunjukan terdapat pengaruh persepsi tentang bacaan dan minat baca terhadap kebiasaan membaca secar asignifikan
\end{abstract}

\section{Kata kunci: Persepsi tentang Taman Bacaan, Minat, Kebiasaan Membaca}

\section{PENDAHULUAN}

Minat baca masyarakat tergolong rendah dibandingkan dengan tingkat minat baca masyarakat bangsa lain. UNDP (United Nations Development Program) tahun 2012 menyatakan bahwa Indeks Pembangunan Manusia berdasarkan angka buta aksara posisi Indonesia berada pada urutan 111 dari 175 negara.Posisi ini berada dibawah Malaysia urutan ke 64 dan Filipina urutan 105 (undp.org)

Salah satu faktor penyebab rendahnya minat baca, karena masih dominan budaya tutur dari pada budaya baca. Selain itu tidak meratanya penyebaran koleksi bahan perpustakaaan dan Taman Bacaan di berbagai lapisan masyarakat serta belum optimalnya pemberdayaanya (Fairbairn, 2005).

Hal ini mempunyai dampak negatifterhadap minat dan kebiasaan masyarakat dalam mengembangkan dirinya menambah ilmu pengetahuan melalui membaca. Pemerintah sendiri sebenarnya sudah mengupayakan agar masyarakat dapat meningkatkan minat dan kebiasaan membaca.

Pada seminar Nasional "Sosialisasi Pengembangan Minat Baca dan pembinaan perpustakaan 2007 "Bapak Jusuf Kalla mengatakan" pengembangan produk fisik minat baca ( Taman bacaan,perpustakaan umum dan yang lainnya), haruslah jelas target kebutuhan masyarakatnya, Pola pembinaan minat dan kebiasaan membaca yang dilakukan oleh Perpustakaan Nasional RI di lingkungan keluarga, Taman Kanak-kanak, Sekolah Dasar, Sekolah Tingkat Pertama, Sekolah Tingkat Atas dan Perguruan Tinggi tidak disesuaikan dengan tipologi kawasan yang berlaku di Indonesia, serta kelangkaan koleksi bahan bacaan dan faktor budaya. 
Sejumlah tempat yang mendapat program Pusat Kegiatan Belajar Masyarakat (PKBM) di Kerawang kecamatan Teluk Jambe Timur, hanya Taman Bacaan Masyarakat (TBM) Bina Sejahtera yang aktif berperan dalam penyedia bacaan bagi masyarakat.

TBM Kebunku di Bekasi kurang pengunjung. Buku-buku yang merupakan hasil sumbangan pemerintah, Sebagian besar masih terlihat baru. Rendahnya Keragaman buku juga menjadi kendala. Sebagai contoh seorang Ibu warga Pekayon yang gemar memasak tapi ketika ia menginginkan buku-buku yang terkait dengan makanan dan minuman tidak tersedia. Sementara buku-buku yang ada lebih banyak buku-buku pengetahuan umum, TBM yang ada terkesan hanya berjalan saja, begitu pula dengan kondisi fisik bangunan TBM, seperti TBM Alflah di jalan Nurul Amal Kampung Cibitung Harapan, Meskipun para pengelolanya antusias, namun jika tidak di dukung sarana yang memadai, maka TBM yang ada akan kurang menarik. Sarana dan prasarana TBM yang seadanya menyebabkan suasana TBM yang kurang nyaman.

Kehadiran TBM, bertujuan untuk ikut mencerdaskan masyarakat yang tidak mampu mengikuti pendidikan di jalur formal, sehingga akan muncul sumber daya manusia yang berkualitas. Pelayanan TBM tidak dikenakan biaya dan tidak dibatasi umur (Dr Dadang Duli seminar membangun Jabar 2007)

Sudah saatnya kondisi TBM diperbaiki dan hal itu akan mewujudkan TBM yang dapat menjadi penyedia saranamembaca yang ideal bagi anak-anak dan masyarakat pada umumnya.

\section{LANDASAN TEORI}

Banyak orang mendefinisikan minat dengan berbagai macam definisi.Definisi minat adalah ciri-ciri keinginan yang dilakukan melalui tindakan oleh seorang individu yang dicobanya melalui objek yang dipilihnya, kegiatanya, ketrampilannya dan ditujukan pada hal-hal yang disukai (Syaifullah, 2001)

Perwujudan minat baca yang dikemukakan itu tidak terlihat sebagai perilaku yang berbeda, tetapi dilihat sebagai sesuatu yang terwujud pada perilaku yang sama, yaitu mewujudkan pada kegiatan membaca. Dalam hal ini minat terpola dan spontan diilhami sebagai faktor pendorong yang menyebabkan terwujudnya perilaku membaca pada murid-murid. Selanjutnya, pengertian minat diartikan sebagai factor eksternal. Sedangkan minat spontan sebagai factor internal. Minat adalah factor kejiwaan yang kompleks dan unik karena perwujudan yang menggejala pada perilaku, sangat dipengaruhi oleh lingkungan dan kejiwaan. Terhadap kekompakan dan keunikan minat itu sekolah, banyak ahli melakukan penelitian yang berupaya memahami kondisi lingkungan dan kejiwaan dalam kaitanya dengan pelacakan mewujudkan kegairahan, rasa senang, intensitas dan situasi kondisi kejiwaan lain yang diperlihatkan manusia dalam meresponsi sesuatu yang dihadapinya atau yang ada di sekitarnya. Atas dasar response yang mengejala pada perilaku itulah secara konkret minat dapat ditangkap, diamati, dan di ukur.

Khusus tentang minat baca murid telah menarik perhatian para ahli terutama dalam kaitanya dengan (1) Usaha pengembangan perpustakaan (2) penyusunan program kerja sama antara pustakawan, dan guru (3) pemilihan bahan-bahan bacaan yang sesuai dengan kesiapan,kematangan dan kebutuhan murid (4) Memahami bahan bacaan yang diminati murid laki-laki dan perempuan 
serta pemberdayaanya dan (5) Berbagai alasan yang melatarbelakangi minat baca murid-murid (Rahayuningsih, 2007).

Definisi minat yang lain adalah karakter yang diatur dari pengalaman yang memaksa seseorang untuk mencari fakta-fakta obyektif, pengertian, percakapan atau pengalaman. Minat sama dengan kecenderungan watak seseorang untuk berusaha terus menerus dalam mencapai suat tujuan. Jika seseorang sudah tumbuh minatnya ia akan terbiasa melakukan suatu kegiatan.

Bunanta menyebutkan bahwa minat baca terutama sangat ditentukan oleh:

1. Faktor lingkungan keluarga dalam hal ini semisal kebiasaan membac keluarga di lingkungan rumah

2. Faktor pendidikan dan kurikulum di sekolah yang kurang kondusif

3. Faktor infrastruktur dalam masyarakat yang kurang mendukung peningkatan minat baca

4. Serta faktor keberadaan dan keterjangkauan bahan bacaan

\section{Kiat-kiat memotivasi minat membaca}

Ada beberapa pendapat pakar pendidikan tentang kiat-kiat memotivasi minat baca:

Menurut Prof.Arief Rachman, 2007 antara lain:

1. Merespon sikap ingin tahu secara positif, yaitu dengan sikap-sikap yang mendorong peningkatan ketrampilan membaca

2. Harus mengetahui momentum.Ketika sedang mengerjakan sesuatu yang kita sukai, misalnya minat atau hobi lain yang menuntut keseriusan atau konsentrasi, janganlah memaksa diri untuk membaca.

3. Tanamkan pemikiran bahwa membaca juga dapat menambah tenaga. Banyak membaca bermanfaat menambah energi sehingga seorang akan bergairah dalam melaksanakan apa yang dia pikirkan.

4. Sistim ganjaran.Berikan hadiah yang merangsang sehingga orang termotivasi dan akhirnya terbiasa membaca.

Pendapat lain menyatakan bahwa "tumbuhnya minat baca tidak dapat dipaksakan dari luar".Minat baca lebih baik timbul atas kesadaran dari dalam diri seseorang" (www.bit.lipi.go.id).

\section{Upaya Meningkatkan Minat Membaca Anak}

Banyak pihak yang memiliki peran dalam menumbuhkan minat baca

\section{Peran Keluarga}

Bagi orang tua, bukan pekerjaan yang mudah untuk memberikan teladan yang baik bagi anak-anak.Khusunya dalam hal membaca. Orang tua diharapkan dapat memberikan dampak yang baik dengan menanamkan kebiasaan membaca pada anak sejak kecil. Mereka dapat mengajak anak-anaknya untuk membuat membuat perpustakaan rumah. Menyediakan buku-buku di rumah, dan meluangkan waktu untuk bersama-sama mengunjungi perpustakaan secara periodik

2. Peran Guru

Para guru dapat mengajak peserta didik untuk membaca buku-buku yang menarik di perpustakaan. Guru dapat mewajibkan peserta didik membaca 
sebuah buku setiap minggu dan orang tua wajib menandatangani laporannya. Sedangkan sekolah dapat menumbuhkan minat baca peserta didik dengan menjadikan perpustakaan bersifat aktif dan kondusif.

3. Peran media cetak dan elektronik

Kecintaan anak-anak akan menonton TV merupakan faktor peninjang bagi media elektronik. Media dapat membantu peningkatanan minat baca, Dengan program-program yang menarik anak, mereka akan senang menonton sambil disisipkan membaca bagi kehidupan. Program TV yang sudah sudah searah dengan program kecintaan membaca seperti: Laptop si unyil, "sesame street" dan masih banyak lagi

4. Perantoko buku dan perpustakaan

Toko buku dan perpustakaan merupakan tempat yang sangat berperan dalam mempromosikan budaya membaca. Koleksi buku yang diperbaharui pada periodik tertentu,akan menambah gairah membaca. Buku yang disediakan menurut Wahyudiati 2008, hendaknya disesuaikan dengan kebutuhan akan informasi peserta didiknya.

a. Anak usia Taman kanak-kanak

Buku-buku bersifat penenalan. Lebih banyak gambar dan memakai warnawarna yang menarik. Buku lebih baik yang berbentuk Hard Cover,sehinggan tidak mudah robek.Buku yang sesuai dengan anak usia ini seperti : Majalah khusus anak,buku-buku alphabet, buku berhitung, bacaan dengan tokoh binatang, legenda asli seperti :sangkuriang, kancil, dan bawang merah bawang putih. Diusia ini minat dan semangat membaca tergantung pada tiga hal 1) kecepatan menunjukkan bahan pelajaran. Dalam hal ini ketika memkai tulisan yang besar di atas kartu besar. 2) Jumlah bahan pelajaran yang selalu baru. 3) Cara mengajar yang menyenangkan (Hasan, 2009:330).

b. Anak usia Sekolah Dasar

Dalam dimensi perkembangan psikologis, anak usia SD bacaanya ringan ygn lebih ringan, bertujuan membangun kesenangan membaca. Pada akhir usia ini, isi bacaan didominasi oleh fungsi pengamatan

c. Anak usia Sekoah Lanjutan tingkat Atas.

Isi bacaan didominasi sebagai fungsi penalaran secara intelektual.Anak selalu mencari pengetahuan dan informasi secara berkesinambungan melalui membaca buku.

5. Peran Pemerintah

Sebagai regulator,pemerintah dituntut untuk dapat menghasilkan peraturan yang mendukung bagi industry buku.Pemerintah dapat berinisiatif bagi ketersediaanya buku- buku bermutu dengan harga terjangkau oleh masyarakat

6. Peran perusahaan swasta

Tiap perusahaan mempunyai tanggung jawab sosial.Tanggung jawab sosial hendaknya dapat diwujudkan dengan membantu pendidikan bagi masyarakat yang kurangmampu.Dengan memberikan sumbangan buku yang berkualitas,maka perusahaan sudah ikut andil dalam peningkatan minat baca masyarakat. 
Langkah-langkah yang dilakukan agar minat baca anak di usia 4-6 tahun,710 tahun dan usiaremaja. Agar semakin baik dan meningkat, Sutan (2004-24) menyarankan langkah-langkah yang harus dilakukan agarminat baca usia 4-6 tahun semakin baik dan meningkat:

1. Gunakan intonasi dan suara yang berbeda-beda saat membacakan

2. Undang teman anak untuk melakukan kegiatan membaca bersam-sama

3. Kegiatan dapat dikembangkan dengan memainkan suatu cerita atau sandiwara panggung

4. Mainkan dan temukan daftar kata dengan ritme hamper menyerupai, misalkan tas, mas dan las. Minta anak untuk menemukan kata-kata seperti itu.

5. Mencari kata-kata yang bunyi atau hurufnya berbeda,misalnya bebek. sapi, bola dan batu, biarkan anak mencari kata yang tidak diawali dengan huruf atau bunyi yang sama

6. Mencari kata-kata yang tidak satu kelompok, misalnya apel, jeruk, bebek dan mangga.Kegiatan ini selain menambah perbendaharaan kosa-katanya, juga mengajarkan untuk menyimak

7. Bermain tebak-tebakan,misalnya minta anak untuk menyebutkan nama binatang yang dimulai dengan huruf $\mathrm{K}$, seperti Komodo, Katak dan yang lainya

8. Adakan pesta buku bertema tertentu, misalnya Teletubbies.

9. Kunjungi perpustakaan atau taman bacaan secara teatur

10. Sediakan papan tulis dengan spidol berwarna, agar mereka dapat berkreasi menulis sembari membaca setiap saat

11. Belikan atau berlangganan buku atau majalah anak yang dikhususkanuntuk anak TK

Kegiatan yang dapat mendorong minat baca pada usia 7-10 tahun adalah;

1. Membuat buku kegiatan. Menempelkan foto-foto kegiatan anak-anak disertai keteranganya

2. Membuat silsilah keluarga

3. Membuat peta rumah dan lingkungan

4. Tanyakan kesan yang diperoleh dari buku yang sudah dibaca

5. Jadikan kegiatan membaca sebagai kegiatan rutin tiap hari

6. Dorong anak untuk menekuni suatu hobi tertentu

7. Sering memberikan hadiah buku kepada anak

8. Jika berkunjung ke toko buku atau perpustakaan, berikan ia kebebasan untuk memilih buku.

Kegiatan yang dapat mendorong minat baca pada usia 11-12 tahun ini adalah;

1. Pilih bacaan menarik,termasuk cerita berseri, anak akan dirangsang untuk mengetahui kelanjutan cerita. Seperti harry Potter

2. Lakukan permainan kata-kata seperti teka-teki silang atau "Scrabble"

3. Mulai merangsang untuk menulis dengan memacu untuk lebih banyak membaca

4. Jika anak mulai menunjukan keinginan yang besar untuk menulis, perkenalkan cara menggunakan kamus, ensiklopedi atau pustaka yang lain. 
Kegiatan yang dapat mendorong minat baca pada usia dewasa adalah:

1. Mulai memperkenalkan dengan ketrampilan membaca yang maju. Mereka dapat memaca secara kritis. Membaca kritis berarti pada saat membaca,pembaca bersikap aktif.

2. Terapkan membaca sistim SQ3R (Douglas Brown 2001) dalam system ini sebelum membaca lakukan survey bacaan, untuk mendapatkan gagasan umum tentang sesuatu yang akan dibaca. Ajukan berbagai pertanyaan $(\mathrm{Q}=$ Question $)$ pada diri sendiri diharapkan terdapat dalam bacaan tersebut, setelah itu proses membaca $(\mathrm{R}=$ reading), selanjutnya mencoba mengutarakan dengan kata-kata sendiri mengenai pokok-pokok bahasa $(\mathrm{R}=$ Recite/recall $)$.

\section{Kebiasaan Membaca}

Kebiasaan membaca hal yang dilakukan berulang-ulang,tanpa adanya perintah dari seseorang. Hal ini dapat dilakukan secara periodic maupun tidak. Demikian juga dengan kebiasaan membaca pada eseorang. Kebiasaan emmbaca yang sudah tertanam dengan baik pada seseorang akan menjadikannya orang yang suka membaca. Bahkan orang ini akan menjadi "maniak membaca" (Sutan, 2004). Kebiasaan membaca (reading habit) dapat dipupuk sejak dini dan dilakukan secara bertahap. Pertama anak dikenalkan dengaan buku yang baik dan menarik, anak akan segera membuka dan melihat. Pada tahap kedua anak diarahkan untuk membaca, khususnya bagi anak yang sudah membaca. Dengan bimbingan dan dukungan keluarga, kebiasaan ini akan bermakna bagi anak kelak. ketiga setelah anak tumbuh dewasa, maka ia akan memerlukan banyak bahan bacaan, anak haus akan bacaan-bacaan yang ia inginbaca. Orang-tua dapat memberikan bahan-bahan yang ia minati oleh anak, sehingga dapat terus memupuk minat dan kebiasaan membaca sampai ia dewasa.

Kebiasaan membaca idealnya muncul dari perhatian dan minat pribadi seseorang. Orang yang menganggap suatu informasi sebagai kebutuhan dasar, akan selalu mencoba untuk menemukan dan menerima informasi. Seperti kebiasaan membaca yang sering dihubungkan dengan pandangan hidup dan tiaptiap individu (Kobarsyih, 2000)

\section{Pengertian Persepsi tentang taman bacaan}

Persepsi adalah cara pandang atau pandangan seorang anak terhadap suatu stimulus atau Rangsang, dan pandangan seseorang mengenai bagaimana individu mengartikan dan menilai sesuatu hal, dalam hal ini taman bacaan. Tiap individu memiliki persepsi yang berbeda terhadap suatu hal atau peristiwa. Perbedaan persepsi dipengaruhi oleh beberapa faktor diantaranya: kepribadian, kecerdasan, kemampuan sosial dan hubungan individu dengan orang lain (Surtieny, 2000). Persepsi anak-anak akan berbeda satu dengan lainya. Dilihat dari pandangan anak-anak,mereka akan melihat Taman Bacaan dari sisi prasarana dan saranya, dari ruanganya, pelayanannya dan yang lainya.

\section{METODOLOGI}

Penelitian ini secara khusus untuk melihat persepsi taman bacaan dan Minat terhadap kebiasaan baca anak di TBM Manca Pekayon Jaya Bekasi Selatan. Dengan menggunakan metode kuantitatif Peneliti akan membandingkan faktor satu dengan lainya, peneliti mengadakan klasifikasi, serta penelitian terhadap 
fenomena-fenomena dengan menetapkan suatu standar atau norma tertentu ,sehingga banyak ahli menamakan metode ini dengan metoda survei normatif (Sugiono, 2004:55)

\section{HASIL DAN PEMBAHASAN}

Penelitian yang dilakukan di Taman Bacaan Manca Pekayon Bekasi sebagai objek penelitian,data diambil melalui kuesioner yang langsung diberikan kepada anggota Taman bacaan Manca,terdapat 35 anggota .

Dapat diketahui bahwa nilai rata-rata membaca sebesar 56,1143, untuk persepsi taman bacaan 58,8571,sedangkan untuk minat sebesar 58,6857.Dengan standard deviasi secara berturut,5,7074,5,33657 dan 5,99397. Hal ini mengandung pengertian persepsi tentang taman bacaan tingkat variansi datanya lebih kecil dari kebiasaan membaca. Sedangkan penyebaran data minat lebih luas dibandingkan kebiasaan membaca.

Tabel 1. Descriptive Statistics

\begin{tabular}{llll}
\hline & Mean & Std.Deviation & $\mathrm{N}$ \\
\hline Kebiasaan membaca & 56.1143 & 5.70743 & 35 \\
Persepsi taman bacaan & 58.8571 & 5.33657 & 35 \\
Minat & 58.6857 & 5.99397 & 35 \\
\hline
\end{tabular}

Analisa Regresi

Analisa ini bertujuan melihat pengaruh varibel independen yaitu minat dan persepsi taman bacaan terhadap variable dependen,yaitu kebiasaan membaca.Hasil ini dilakukann dengan menggunakan SPSS 16 yang disajikan dalam tabel berikut:

Tabel 2. Model Summary

\begin{tabular}{lllll}
\hline Model & $\mathrm{R}$ & $\mathrm{R}$. Square & $\begin{array}{l}\text { Adjusted } \\
\text { Square }\end{array}$ & $\begin{array}{l}\text { R } \\
\text { Std Error of the } \\
\text { estimate }\end{array}$ \\
\hline 1 & .640 & .410 & .373 & 4.51856 \\
\hline
\end{tabular}

Dalam tabel model summary dihasilkan $\mathrm{R}$ sebesar 0,640. Hasil itu menunjukan bahwa 64 persen persepsi tentang taman bacaan dan minat berhubungan dengan kebiasaan membaca.

Tabel diatas menjelaskan prosentase pengaruhvariabel bebas terhadap variabel terikat.Besar koefesien determinasi adalah 0,410 mengandung pengertian bahwa pengaruh variable bebas terhadap variabel terikat adalah 41 persen,sedangkan 59 persen dipengaruhi oleh variabel lain.

Tabel 3. Hasil Regresi Berganda

\begin{tabular}{lll}
\hline \multicolumn{1}{c}{ Model } & \multicolumn{1}{c}{$\begin{array}{c}\text { Unstandardized } \\
\text { Coefficients }\end{array}$} & Std .Error \\
\hline Constant & 10.971 & 9.846 \\
Persepsi taman bacaan & .328 & .156 \\
Minat & .440 & .139 \\
\hline
\end{tabular}

a.Dependent variable kebiasaan membaca 
Tabel 4 .Hasil uji simultan

\begin{tabular}{cc}
\multicolumn{2}{c}{ ANOVA } \\
\hline $\mathrm{F}$ & Sig. \\
\hline 11.123 & .000 \\
\hline
\end{tabular}

Dari tabel 4 yang disajikan di atas dapat diketahui tingkat sig sebesar 0.000 lebih kecil dari 0.05 berarti Ho ditolak. Dapat diartikan variabel persepsi taman bcaan dan minat secara bersama-sama mempengaruhi kebiasaan membaca.

Tabel 5 .Hasil Uji Parsial

\begin{tabular}{lcc}
\hline \multicolumn{1}{c}{ Variabel } & $\mathrm{t}$ & $\mathrm{sig}$ \\
\hline Kebiasaan Membaca & 1.114 & .273 \\
Persepsi taman bacaan & 2.109 & .043 \\
Minat & 3.174 & .003 \\
\hline
\end{tabular}

Nilai t hitung persepsi (X1) sebesar 2,109 dan tabel untuk $\mathrm{N}=35$ adalah 2.04,sehingga nilai thitung lebih besar dari t tabel, atau dapat ditulis 2,109 > 2,04, dengan tingkat signifikansi $=0,003$. Nilai signifikansi dari persepsi adalah 0,043 , sehingga dapat disimpulkan nilai signifikansi dari persepsi taman bacaan lebih kecil dari 0,05. Sehingga Ho di tolak dan Ha diterima,maka keadaan ini menunjukan bahwa terdapat pengaruh positif antara persepsi anak dengan kebiasaan membaca (Y)di taman bacaan Manca Pekayon Bekasi

Nilai $\mathrm{t}$ hitung minat (X2) sebesar 3,174 dan tabel untuk $\mathrm{N}=35$ adalah 2.04,sehingga nilai thitung lebih besar dari t tabel, atau dapat ditulis 3,174 > 2,04, dengan tingkat signifikansi $=0,003$. Nilai signifikansi dari minat baca adalah 0,003, sehingga dapat disimpulkan nilai signifikansi dari persepsi taman bacaan dan minat baca lebih kecil dari 0,05. Sehingga Ho di tolak dan Ha diterima, maka keadaan ini menunjukan bahwa terdapat pengaruh positif antara minat dengan kebiasaan membaca (Y) di taman bacaan Manca Pekayon Bekasi

Sedangkan hasilanalisis dengan uji Anova didapat F hitung 11,123 dengan tingkat signifikan 0,000. tingkat signifikan lebih rendah dari nilai alfa 0,005 atau $0,000<$ 0,05 maka dapat dikatakan bahwa persepsi tentang tamanbacaan dan minat secara bersama-sama berpengaruh terhadap kebiasaan membaca di Taman Bacaan Manca Pekayon Bekasi

\section{SIMPULAN}

1. Terdapat pengaruh yang signifikan persepsi taman bacaan terhadap kebiasaan membaca

2. Terdapat pengaruh yang signifikan minat terhadap kebiasaan membaca

3. Terdapat pengaruh yang signifikan persepsi tentang taman bacaan dan minat secara bersama-sama terhadap kebiasaan membaca.

\section{SARAN}

Saran untuk pengelolaan taman bacaan hendaknya dikelola dengan baik, agar membantu program gemar membaca. Pihak-pihak yang berkepentingan harus 
dapat mengoptimalkan keberadaan taman bacaan ini. Disamping itu pengelola Taman Bacaan melakukan perbaikan dan penyempurnaan program melalui kerjasama antar lembaga, seperti contoh mengadakan lomba dan acara yang menarik, bekerjasama dengan pihak sekolah atau instansi terkait/Sehingga Bangsa Indonesia dapat meningkatan kualitas pembangunan manusia dan mengejar ketertinggalannya dari bangsa lain.

\section{DAFTAR PUSTAKA}

Fairbairn. 2005. Budaya Membaca di Universitas. Jakarta Indeks.

Hartono. 2008. SPSS 16.0Analisis Data Statistik dan penelitian. Pustaka Pelajar

Ibrahim B. 2008. Pengelolaan Perpustakaan Sekolah.Jakarta.Bumi Aksara

Kobarsyih B. 2000.Minat Baca Anak. Yoyakarta. Pinus Book .

Maimunah H. 2009. Pendidikan Anak Usia Dini.Jogya. Diva Press

Rahayuningsih F. 2007. Pengelolaan Perpustakaan. Yogya. Graha Ilmu.

Rahman A. dkk. 1998. Minat Baca Murid SD di JawaTimur.Pengembangan Bahasa Depdikbud

Sugiono. 2004 Statistik. PT Indeks Jakarta

Surtieny. 2000. Psikologi Anak..Jakarta .Gaung Persada press.

Sutan F. 2004. Tiga Langkah Praktis Menjadikan Anak Aniak Membaca. pusps swara

Syaifulloh A.R. 2001. MinatBaca. Jakarta. Cahaya press.

\section{Internet;}

http//pr.qiandri.net taman bacaan masyarakat masih belum termanfaatkan http//rafkirashiid.com makna membangkitkan minat baca. 